\title{
PENGATURAN HUKUM PERBATASAN NEGARA KESATUAN REPUBLIK INDONESIA BERDASARKAN UNDANG-UNDANG WILAYAH NEGARA
}

Oleh:

\author{
Dr. Jeanne Darc Noviayanti Manik, S.H., M.Hum.* \\ Email: novi_palembang@yahoo.com
}

\begin{abstract}
The arrangements area of the country is done to provide legal certainty and clarity to citizens on the territory of the country. Area of the country as outlined in the Constitution of the Republic of Indonesia Year 1945 has an arrangement the Government of Indonesia that protects the Nations Indonesia, the utilization of earth, water, and air as well as the natural resources contained therein for the most of people's prosperity, decentralization of Government to the areas large and small that are autonomous in the frame of the unitary State of the Republic of Indonesia; and social welfare for all the people of Indonesia.
\end{abstract}

Keyword: Territory, Border Country, Nation, The People

\section{A. PENDAHULUAN}

Negara Kesatuan Republik Indonesia, ${ }^{1}$ sebagai negara kepulauan yang berciri nusantara mempunyai kedaulatan atas wilayah serta memiliki hak-hak berdaulat di luar wilayah kedaulatannya untuk dikelola dan dimanfaatkan sebesar-besarnya bagi kemakmuran rakyat Indonesia sebagaimana diamanatkan dalam pembukaan Undang-Undang Dasar Negara Republik Indonesia Tahun 1945. Undang-Undang Dasar Negara Republik Indonesia Tahun 1945 Pasal 25A mengamanatkan bahwa Negara

*Dosen Tetap Fakultas Hukum Universitas Bangka Belitung.

${ }^{1}$ Dalam Undang-Undang Dasar Negara Republik Indonesia ditentukan, bahwa Negara Indonesia ialah Negara Kesatuan, yang berbentuk Republik. Periksa UUD NRI Tahun 1945.
Kesatuan Republik Indonesia adalah sebuah negara kepulauan yang berciri Nusantara dengan wilayah yang batasbatas danhak-haknya ditetapkan dengan undang-undang.

Pengaturan wilayah negara sebagaimana dimaksud dalam huruf $b$ dilakukan untuk memberikan kepastian hukum dan kejelasan kepada warga negara mengenai wilayah negara. Wilayah negara sebagaimana dimaksud dalam Undang-Undang Dasar Negara Republik Indonesia Tahun 1945 menganut sistem:;

1. Pengaturan suatu Pemerintahan negara Indonesia yang melindungi segenap bangsa Indonesia dan seluruh tumpah darah Indonesia; 
2. Pemanfaatan bumi, air, dan udara serta kekayaan alam yang terkandung di dalamnya untuk sebesar-besarnya kemakmuran rakyat;

3. Desentralisasi pemerintahan kepada daerah-daerah besar dan kecil yang bersifat otonom dalam bingkai Negara Kesatuan Republik Indonesia; dan

4. Kesejahteraan sosial bagi seluruh rakyat Indonesia.

Dalam rangka untuk mengejawantahkan maksud UndangUndang Dasar Negara Republik Indonesia Tahun 1945 tersebut diperlukan, pengaturan-pengaturan kewilayahan secara nasional, antara lain pengaturan mengenai:

1. Perairan;

2. Daratan/tanah;

3. Udara;

4. Ruang; dan

5. Sumber kekayaan alam dan lingkungannya.

Mengingat sisi terluar dari wilayah negara atau yang dikenal dengan Kawasan Perbatasan merupakan kawasan strategis dalam menjaga integritas Wilayah Negara, maka diperlukan juga pengaturan secara khusus. Pengaturan batas-batas Wilayah Negara dimaksudkan untuk memberikan kepastian hukum mengenai ruang lingkup wilayah negara, kewenangan pengelolaan Wilayah Negara, dan hak-hak berdaulat.

Negara berkepentingan untuk ikut mengatur pengelolaan dan pemanfaatan di laut bebas dan dasar laut internasional sesuai dengan hukum internasional. Pemanfaatan di laut bebas dan di dasar laut meliputi pengelolaan kekayaan alam, perlindungan lingkungan laut dan keselamatan navigasi. Pengelolaan Wilayah Negara dilakukan dengan pendekatan kesejahteraan, keamanan dan kelestarian lingkungan secara bersama-sama. Pendekatan kesejahteraan dalam arti upaya-upaya pengelolaan Wilayah Negara hendaknya memberikan manfaat sebesar-besarnya bagi peningkatan kesejahteraaan masyarakat yang tinggal di Kawasan Perbatasan. Pendekatan keamanan dalam arti pengelolaan Wilayah Negara untuk menjamin keutuhan wilayah dan kedaulatan negara serta perlindungan segenap bangsa. Pendekatan kelestarian lingkungan dalam arti pembangunan Kawasan Perbatasan yang memperhatikan aspek kelestarian lingkungan yang merupakan wujud dari pembangunan yang berkelanjutan. Peran Pemerintah dan Pemerintah 
Daerah menjadi sangat penting terkait dengan pelaksanaan fungsi-fungsi pemerintahan sesuai dengan prinsip otonomi daerah dalam mengelola pembangunan Kawasan Perbatasan.

Dalam Undang-Undang No. 43 Tahun 2008 tentang Wilayah Negara (selanjutnya disebut UU Wilayah Negara) pada Pasal 2, Pengaturan Wilayah Negara dilaksanakan berdasarkan asas:

1. Kedaulatan;

2. Kebangsaan;

3. Kenusantaraan;

4. Keadilan;

5. Keamanan;

6. Ketertiban dan kepastian hukum;

7. Kerja sama;

8. Kemanfaatan; dan

9. Pengayoman.

Dalam UU Wilayah Negara pada Pasal 3, disebutkan pengaturan Wilayah Negara bertujuan:

1. Menjamin keutuhan Wilayah Negara, kedaulatan negara, dan ketertiban di Kawasan Perbatasan demi kepentingan kesejahteraan segenap bangsa;

2. Menegakkan kedaulatan dan hakhak berdaulat; dan

3. Mengatur pengelolaan dan pemanfaatan Wilayah Negara dan Kawasan Perbatasan, termasuk pengawasan batas-batasnya.
Dalam UU Wilayah Negara pada Pasal 4 dinyatakan bahwa Wilayah Negara meliputi wilayah darat, wilayah perairan, dasar laut, dan tanah di bawahnya serta ruang udara di atasnya, termasuk seluruh sumber kekayaan yang terkandung di dalamnya.

UU Wilayah Negara pada Pasal 5, dinyatakan bahwa batas Wilayah Negara di darat, perairan, dasar laut dan tanah di bawahnya serta ruang udara di atasnya ditetapkan atas dasar perjanjian bilateral dan/atau trilateral mengenai batas darat, batas laut, dan batas udara serta berdasarkan peraturan perundang-undangan dan hukum internasional.

Dalam UU Wilayah Negara pada Pasal 6 diatur bahwa:

(1)Batas Wilayah Negara sebagaimana dimaksud dalam Pasal 5, meliputi:

a. di darat berbatas dengan Wilayah Negara: Malaysia, Papua Nugini, dan Timor Leste;

b. di laut berbatas dengan Wilayah Negara: Malaysia, Papua Nugini, Singapura, dan Timor Leste; dan

c. di udara mengikuti batas kedaulatan negara di darat dan di laut, dan batasnya dengan angkasa luar ditetapkan berdasarkan perkembangan hukum internasional. 
(2)Batas Wilayah Negara sebagaimana dimaksud pada ayat (1), termasuk titik-titik koordinatnya ditetapkan berdasarkan perjanjian bilateral dan/atau trilateral.

(3)Dalam hal Wilayah Negara tidak berbatasan dengan negara lain, Indonesia menetapkan Batas Wilayah Negara secara unilateral berdasarkan peraturan perundang-undangan dan hukum internasional.

Penetapan Batas Wilayah Negara dilakukan melalui perjanjian bilateral dan/atau trilateral apabila terdapat dua atau tiga negara yang menyatakan pengakuan atas wilayah yang sama ataupun adanya kemungkinan tumpang-tindih pengakuan atas wilayah yang sama. Penetapan Batas Wilayah Negara dilakukan secara unilateral apabila tidak terdapat pengakuan atas wilayah yang sama ataupun tidak adanya kemungkinan tumpang-tindih pengakuan atas wilayah yang sama.

Batas Wilayah Yurisdiksi diatur dalam Pasal 8, bahwa:

(1)Wilayah Yurisdiksi Indonesia berbatas dengan wilayah yurisdiksi Australia, Filipina, India, Malaysia, Papua Nugini, Palau, Thailand, Timor Leste, dan Vietnam.

(2)Batas Wilayah Yurisdiksi sebagaimana dimaksud pada ayat (1) termasuk titik-titik koordinatnya ditetapkan berdasarkan perjanjian bilateral dan/atau trilateral.
(3)Dalam hal Wilayah Yurisdiksi tidak berbatasan dengan negara lain, Indonesia menetapkan Batas Wilayah Yurisdiksinya secara unilateral berdasarkan ketentuan peraturan perundangundangan dan hukum internasional.

Dalam UU Wilayah Negara pada Pasal 9, Pemerintah dan pemerintah daerah berwenang mengatur pengelolaan dan pemanfaatan Wilayah Negara dan Kawasan Perbatasan. Lebih lanjut, dalam Pasal 10 ditentukan, bahwa:

(1)Dalam pengelolaan Wilayah Negara dan Kawasan Perbatasan, Pemerintah berwenang:

a. menetapkan kebijakan pengelolaan dan pemanfaatan Wilayah Negara dan Kawasan Perbatasan;

b. mengadakan perundingan dengan negara lain mengenai penetapan Batas Wilayah Negara sesuai dengan ketentuan peraturan perundang-undangan dan hukum internasional;

c. membangun atau membuat tanda Batas Wilayah Negara;

d. melakukan pendataan dan pemberian nama pulau dan kepulauan serta unsur geografis lainnya;

e. memberikan izin kepada penerbangan internasional untuk melintasi wilayah udara teritorial pada jalur yang telah ditentukan dalam peraturan perundangundangan;

f. memberikan izin lintas damai kepada kapal-kapal asing untuk melintasi laut teritorial 
dan perairan kepulauan pada jalur yang telah ditentukan dalam peraturan perundangundangan;

g. melaksanakan pengawasan di zona tambahan yang diperlukan untuk mencegah pelanggaran dan menghukum pelanggar peraturan perundang-undangan di bidang bea cukai, fiskal, imigrasi, atau saniter di dalam Wilayah Negara atau laut teritorial;

h. menetapkan wilayah udara yang dilarang dilintasi oleh penerbangan internasional untuk pertahanan dan keamanan;

i. membuat dan memperbarui peta Wilayah Negara dan menyampaikannya kepada Dewan Perwakilan Rakyat sekurang-kurangnya setiap 5 (lima) tahun sekali; dan $\mathrm{j}$. menjaga keutuhan, kedaulatan, dan keamanan Wilayah Negara serta Kawasan Perbatasan.

(2)Dalam rangka melaksanakan ketentuan sebagaimana dimaksud pada ayat (1), Pemerintah berkewajiban menetapkan biaya pembangunan Kawasan Perbatasan.

(3)Dalam rangka menjalankan kewenangannya, Pemerintah dapat menugasi pemerintah daerah untuk menjalankan kewenangannya dalam rangka tugas pembantuan sesuai dengan peraturan perundang-undangan.

Kawasan perbatasan negara memiliki potensi dan peluang untuk berkembang dengan baik, jikalau sejumlah kendala dan hambatan mendasar yang juga telah menyebabkan berbagai masalah mendasar, seperti rendahnya taraf kehidupan masyarakat, tingginya kesenjangan sosial dan ekonomi, masalah politik, keamanan dan ketertiban dapat dikelola demi pemecahannya dengan baik, melalui kebijakan yang lebih baik dalam arti lebih terintegrasi dan menyeluruh dengan semangat pembaharuan dan perubahan pada berbagai aspek/dimensinya, seperti hal pembaharuan dan perubahan paradigma berpikir dan strategi, aturan, organisasi dan tata kelola termasuk bidangbidang pengelolaan; serta dukungan sumberdaya. Sedemikian rupa proses dari semua hal itu, sehingga terciptanya kondisi yang lebih menjamin proses dan pencapaian tujuan pembangunan nasional umumnya dan pengelolaan batas negara dan kawasan perbatasan khususnya. ${ }^{2}$ Kemudian di dalam Pasal 11 ditentukan, bahwa: (1)Dalam pengelolaan Wilayah Negara dan Kawasan Perbatasan, Pemerintah Provinsi berwenang:

a. melaksanakan kebijakan Pemerintah dan menetapkan kebijakan lainnya dalam

\footnotetext{
${ }^{2}$ Lerry Rupidara,Policy Paper Pengelolaan Batas Negara dan Kawasan Perbatasan, Badan Pengelolaan Perbatasan Provinsi NTT, Kupang,2010, hlm.1.
} 
rangka otonomi daerah dan tugas pembantuan;

b. melakukan koordinasi pembangunan di Kawasan Perbatasan;

c. melakukan pembangunan Kawasan Perbatasan antarpemerintah daerah dan/atau antara pemerintah daerah dengan pihak ketiga; dan

d. melakukan pengawasan pelaksanaan pembangunan Kawasan Perbatasan yang dilaksanakan Pemerintah Kabupaten/Kota.

(2)Dalam rangka melaksanakan ketentuan sebagaimana dimaksud pada ayat (1), Pemerintah Provinsi berkewajiban menetapkan biaya pembangunan Kawasan Perbatasan.

Kemudian Pasal 12 ditentukan, bahwa:

(1)Dalam pengelolaan Wilayah Negara dan Kawasan Perbatasan, Pemerintah Kabupaten/Kota berwenang:

a. melaksanakan kebijakan Pemerintah dan menetapkan kebijakan lainnya dalam rangka otonomi daerah dan tugas pembantuan;

b. menjaga dan memelihara tanda batas;

c. melakukan koordinasi dalam rangka pelaksanaan tugas pembangunan di Kawasan Perbatasan di wilayahnya; dan

d. melakukan pembangunan Kawasan Perbatasan antarpemerintah daerah dan/atau antara pemerintah daerah dengan pihak ketiga.

(2)Dalam rangka melaksanakan ketentuan sebagaimana dimaksud pada ayat (1),
Pemerintah Kabupaten/Kota berkewajiban menetapkan biaya pembangunan Kawasan Perbatasan.

\section{B. PEMBAHASAN}

Batas Wilayah Negara adalah garis batas yang merupakan pemisah kedaulatan suatu negara yang didasarkan atas hukum internasional. ${ }^{3}$ Kawasan Perbatasan adalah bagian dari Wilayah Negara yang terletak pada sisi dalam sepanjang batas wilayah Indonesia dengan negara lain, dalam hal Batas Wilayah Negara di darat, Kawasan Perbatasan berada di kecamatan. ${ }^{4}$ Batas Wilayah Yurisdiksi adalah garis batas yang merupakan pemisah hak berdaulat dan kewenangan tertentu yang dimiliki oleh negara yang didasarkan atas ketentuan peraturan perundangundangan dan hukum internasional. ${ }^{5}$

Masalah perbatasan merupakan bagian dari masalah petahanan dan keamanan negara. Oleh karena itu, setiap negara berwenang menentukan batas wilayah yurisdiksinya masingmasing. Namun penetapan batas wilayah juga harus memperhatikan kewenangan otoritas negara lain

\footnotetext{
${ }^{3}$ Periksa Pasal 1 ayat (4) Undang-Undang Nomor 43 Tahun 2008 tentang Wilayah Negara.

${ }^{4}$ Periksa Pasal 1 ayat (6) Undang-Undang Nomor 43 Tahun 2008 tentang Wilayah Negara.

${ }^{5}$ Periksa Pasal 1 ayat (5) Undang-Undang Nomor 43 Tahun 2008 tentang Wilayah Negara.
} 
melalui suatu kerjasama dan perjanjian bilateral. Misalnya, dalam bidang survey dan penentuan batas wilayah darat maupun laut antara Indonesia dengan negara lain, selama ini masih tertuang dalam suatu bentuk MOU maupun perjanjian-perjanjian penetapan garis batas laut antarnegara. Terkait dengan hal itu, UUD Negara Republik Indonesia tahun 1945, dalam Pasal 25A memerintahkan pembuatan UU kepada pemerintah untuk menentukan batas wilayah negara yang dapat dijadikan pedoman dalam mempertahankan kedaulatan Indonesia, memperjuangkan kepentingan nasional, dan keselamatan bangsa, memperkuat potensi, memberdayakan dan mengembangkan sumber daya alam bagi kemakmuran seluruh bangsa Indonesia. $^{6}$

Undang-undang Tentang Wilayah Negara dalam Pasal 6 ayat (2) yang menyatakan : (2) Batas Wilayah Negara sebagaimana dimaksud pada ayat (1), termasuk titik-titik koordinatnya ditetapkan berdasarkan

\footnotetext{
${ }^{6}$ Moh. Mahmud MD., "Tata Kelola Perbatasan Negara Kita",Makalah,Disampaikan dalam acara Seminar Forum Rektor Indonesia: Keunggulan, Kepeloporan, Kejuangan dan Pengabdian Perguruan Tinggi dalam Membangun Daya Saing dan Martabat Bangsadi Auditorium Kahar Mudzdhakir, UII, Yogyakarta, 5 Agustus 2008, hlm. 5.
}

perjanjian bilateral dan/atau

trilateral. Berdasarkan penelitian yang dilakukan oleh Bappeda Provinsi D.I Yogyakarta bekerjasama dengan Lembaga Penelitian P4N UGM tahun 1993, wilayah perbatasan dapat dikelompokkan dalam 3 (tiga) tipe, yaitu: ${ }^{7}$

a. Wilayah buntu, dicirikan oleh: (1) posisi pada ujung jaringan atau bahkan belum terjangkau oleh sistem jaringan yang merangkai tempat tersebut dengan pusat pelayanan hirarkhi terendah dalam sistem wilayah yang membawahinya atau dengan perkotaan lain; (2) terletak pada lahan marginal karena sifat geologi wilayahnya (seperti: morfologi, lereng, batuan, dan tanah); (3) kepadatan penduduk rendah; dan (4) proyek pengembangan sangat terbatas karena faktor ekologis;

b. Wilayah perbatasan jalur perifer, dicirikan oleh: (1) terlewati sistem jaringan jalan yang merangkai tempat tersebut dengan sistem wilayah yang membawahinya, maupun dengan sistem seberang perbatasan; (2) terletak pada wilayah dengan kegiatan ekonomi sedang; dan (3) prospek pengembangan sangat tergantung wilayah yang secara langsung terangkai menjadi satu kesatuan wilayah atau kesatuan sistem jaringan dengan wilayah tersebut;

c. Wilayah perbatasan kontak tinggi, dicirikan oleh: (1) posisi antar wilayah utama; (2) intensitas kegiatan ekonomi pada satu sisi

\footnotetext{
${ }^{7}$ Listiyah Miniarti dalamAziz Budianta, "Pengembangan Wilayah Perbatasan Sebagai Upaya Pemerataan Pembangunan Wilayah Di Indonesia", Jurnal SMARTek Volume 8 Nomor 1, Pebruari 2010, hlm. $72-82$.
} 
atau pada kedua sisi pembatas; (3) kepadatan penduduk relatif tinggi; dan (4) terdapat aglomerasi penduduk dan pusat pelayanan yang melayani kebutuhan penduduk pada kedua sisi perbatasan.

Masalah penegasan batas wilayah di dalam sebuah UU menjadi semakin penting sejalan terjadinya perubahan yang cepat di berbagai kawasan akibat pengaruh situasi global. Masalah batas wilayah negara bukan hanya menyangkut ancaman dari luar, tetapi juga terkait dengan masalah kedaulatan wilayah dan hak setiap warga negara untuk mengeksploitasi kekayaan alamnya. Karena sumber kekayaan yang makin terbatas sedangkan jumlah penduduk yang makin bertambah, maka perbatasan menjadi sensitif bagi timbulnya perselisihan (disputes) dan konflik. Oleh karena itu, penting bagi Indonesia dan negara-negara yang berbatasan wilayah baik darat maupun laut dengan Indonesia untuk membuat suatu produk hukum internasional yang lebih sifat mengikatnya kuat seperti misalnya pejanjian internasional atau treaty. Dalam Pasal 62 ayat (2) Konvensi Wina 1969 mengenai Perjanjian Internasional menyatakan bahwa klausula rebus sic stantibus 13 tidak dapat diberlakukan terhadap perjanjian internasional yang mengatur mengenai perbatasan negara.

Nilai-nilai yang terkandung dalam kawasan perbatasan adalah: ${ }^{8}$

1. Nilai kedaulatan

2. Nilai nasionalisme

3. Nilai kesetaraan, kesepakatan dan kerjasama

4. Nilai pembangunan negara

5. Nilai hukum / kepastian hukum

6. Nilai pertahanan keamanan

7. Nilai politis

8. Nilai ekonomi/kesejahteraan

9. Nilai sosial

10. Nilai budaya

11. Nilai ideologi

12. Nilai geografis dan spasial.

Untuk mengelola Batas Wilayah Negara dan mengelola Kawasan Perbatasan pada tingkat pusat dan daerah, Pemerintah dan pemerintah daerah membentuk Badan Pengelola Nasional dan Badan Pengelola daerah. Badan Pengelola dipimpin oleh seorang kepala badan yang bertanggung jawab kepada Presiden atau kepala daerah sesuai dengan kewenangannya. Keanggotaan Badan Pengelola berasal dari unsur Pemerintah dan pemerintah daerah

\footnotetext{
${ }^{8}$ Mahendra Putra Kurnia, Harmonisasi Hukum Pengembangan Kawasan Perbatasan NKRI Berbasis Teknologi Geospasial, UB Press, Malang, 2011, hlm. 71.
} 
yang terkait dengan perbatasan

Wilayah Negara.

Badan Pengelola bertugas:

1. Menetapkan kebijakan program pembangunan perbatasan;

2. Menetapkan rencana kebutuhan anggaran;

3. Mengoordinasikan pelaksanaan; dan

4. Melaksanakan evaluasi dan pengawasan.

Badan Nasional Pengelola

Perbatasan yang selanjutnya disebut

BNPP adalah Badan Pengelola Batas

Wilayah Negara dan Kawasan

Perbatasan sebagaimana dimaksud

Undang-Undang Nomor 43 Tahun

2008 tentang Wilayah Negara.

Penjabaran lebih lanjut mengenai BNPP, dilaksanakan dalam Peraturan Presiden No.12 Tahun 2010 tentang Badan Nasional Pengelola Perbatasan (selanjutnya disebut Perpres BNPP) yang pada Pasal 3 menentukan bahwa BNPP mempunyai tugas menetapkan kebijakan program pembangunan perbatasan, menetapkan rencana kebutuhan anggaran, mengoordinasikan pelaksanaan, dan melaksanakan evaluasi dan pengawasan terhadap pengelolaan Batas Wilayah Negara dan Kawasan Perbatasan.
Dalam Perpres BNPP pada Pasal 4, dinyatakan Untuk melaksanakan tugas sebagaimana dimaksud dalam Pasal 3, BNPP menyelenggarakan fungsi:

1. Penyusunan dan penetapan rencana induk dan rencana aksi pembangunan Batas Wilayah Negara dan Kawasan Perbatasan;

2. Pengoordinasian penetapan kebijakan dan pelaksanaan pembangunan, pengelolaan serta pemanfaatan Batas Wilayah Negara dan Kawasan Perbatasan;

3. Pengelolaan dan fasilitasi penegasan, pemeliharaan dan pengamanan Batas Wilayah Negara;

4. Inventarisasi potensi sumber daya dan rekomendasi penetapan zona pengembangan ekonomi, pertahanan, sosial budaya, lingkungan hidupdan zona lainnya di Kawasan Perbatasan;

5. Penyusunan program dan kebijakan pembangunan sarana dan prasarana perhubungan dan sarana lainnya di Kawasan Perbatasan;

6. Penyusunan anggaran pembangunan dan pengelolaan Batas Wilayah Negara dan Kawasan Perbatasan sesuai dengan skala prioritas;

7. Pelaksanaan, pengendalian dan pengawasan serta evaluasi dan 
pelaporan pelaksanaan pembangunan dan pengelolaan

Batas Wilayah Negara dan

Kawasan Perbatasan.

Dalam konteks politik modern, pengelolaan wilayah perbatasan secara efektif dan terus-menerus dapat dilihat tidak hanya perlu kehadiran simbolsimbol pelaksanaan kepemerintahan negara yang bersangkutan tetapi juga sejauh mana politik dan pendekatan pembangunan yang dilakukan di wilayah-wilayah dimaksud dapat dirasakan manfaatnya bagi rakyat setempat dan diakui reputasinya oleh negara-negara lainnya. Secara lebih konkrit NKRI, pengelolaan wilayah perbatasan harus digunakan paradigma baru yang menjadikan wilayah perbatasan tidak lagi menjadi pagar belakang tetapi merupakan beranda depan suatu negara. Dengan demikian, dalam pengelolaan wilayah perbatasan, politik pembangunan yang ditempuh dengan paradigma baru tersebut sebagai contoh dapat diwujudkan dengan sejauh mana Indonesia dapat mendesain sebuah rencana induk pengelolaan perbatasan secara nasional dan terpadu. ${ }^{9}$

\footnotetext{
${ }^{9}$ Sri Haryati dan Ahmad Yani, Geografi Politik, PT. Refika Aditama, Bandung,2007, hlm.7.
}

Pada wilayah perbatasan ini juga menyimpan banyak masalah laten yang kalau tidak diselesaikan akan sangat merugikan kedua belah pihak khususnya masyarakat yang berdiam pada wilayah tersebut. Bahaya laten tersebut salah satunya adalah konflik perebutan lahan yang sering sekali terjadi antara masyarakat di wilayah tersebut. Terdapat empat jenis perbatasan yang sering kali memunculkan konflik, yaitu: (1) Territorial, dimana suatu Negara/daerah mengaku suatu kawasan tertentu sebagai milik yang sah, (2) Positional, dimana suatu Negara/daerah mempermasalahkan definisi dan demarkasi tentang batasbatasnya dengan Negara/daerah yang lainnya, (3) Functional, suatu Negara mempunyai perselisihan paham tentang penggunaan fungsifungsi dari objek yang ada di kawasan perbatasan, (4) Resources Based, dimana suatu Negara/ daerah bersaing untuk mendapatkan penguasaan atas suatu negara/daerah bersaing untuk mendapatkan penguasaan atas suatu daerah tapal batas. ${ }^{10}$

\footnotetext{
${ }^{10}$ Ane Permatasari, "Otonomi Khusus Daerah Perbatasan, Alternatif Solusi Penyelesaian Masalah Perbatasan Di Indonesia”, Jurnal Media Hukum Volume 21 Nomor 2 Desember 2014, hal.227.
} 
Kejelasan titik-titik perbatasan wilayah Indonesia akan berimplikasi terhadap pelaksanaan kedaulatan negara secara damai dalam pengelolaan perbatasan, sebab perbatasan merupakan manifestasi utama kedaulatan wilayah negara di garis depan pemanfaatan sumber daya alam, menjaga keamanan dan keutuhan wilayah. Sebaliknyam jika titik-titik perbatasan tidak jelas, maka akan memunculkan potensi sengketa dengan negara tetangga. ${ }^{11}$

Dalam Undang-Undang Republik Indonesia Nomor 43 Tahun 2008 Tentang Wilayah Negara pada Pasal 19 diatur tentang Peran Serta Masyarakat, bahwa:

(1)Peran serta masyarakat dalam pengelolaan Kawasan Perbatasan dilakukan dalam bentuk:

a. mengembangkan pembangunan Kawasan Perbatasan; dan

b. menjaga serta mempertahankan Kawasan Perbatasan.

(2)Untuk melaksanakan ketentuan sebagaimana dimaksud pada ayat (1), Pemerintah dapat melibatkan masyarakat untuk ikut berperan serta dalam pengelolaan Kawasan Perbatasan.

\footnotetext{
${ }^{11}$ Eddy MT Sianturidan Nafsiah, "Strategi Pengembangan Perbatasan Wilayah Kedaulatan NKRI", Majalah Balitbang Dephan, Jakarta, 2001, hal.2. Lihat juga DPD RI, Pandangan dan Pendapat DPD RI terhadap Rancangan UndangUndang tentang Wilayah Negara, Jakarta, 3 Maret 2008, hal.2.
}

Masyarakat Hukum Adat adalah sekelompok orang yang secara turuntemurun bermukim di wilayah geografis tertentu di Negara Kesatuan Republik Indonesia karena adanya ikatan pada asal usul leluhur, hubungan yang kuat dengan tanah, wilayah, sumber daya alam, memiliki pranata pemerintahan adat, dan tatanan hukum adat di wilayah adatnya sesuai dengan ketentuan peraturan perundang-undangan.

Masyarakat Lokal adalah kelompok Masyarakat yang menjalankan tata kehidupan sehari-hari berdasarkan kebiasaan yang sudah diterima sebagai nilai-nilai yang berlaku umum, tetapi tidak sepenuhnya bergantung pada Sumber Daya Pesisir dan Pulau-Pulau Kecil tertentu. ${ }^{12}$ Masyarakat Tradisional adalah Masyarakat perikanan tradisional yang masih diakui hak tradisionalnya dalam melakukan kegiatan penangkapan ikan atau kegiatan lainnya yang sah di daerah tertentu yang berada dalam perairan kepulauan sesuai dengan kaidah hukum laut internasional. ${ }^{13}$

\footnotetext{
${ }^{12}$ Pasal 1 ayat (33) Undang-Undang Republik Indonesia Nomor 1 Tahun 2014 Tentang Perubahan Atas Undang-Undang Nomor 27 Tahun 2007 Tentang Pengelolaan Wilayah Pesisir dan Pulau-Pulau Kecil.

${ }^{13}$ Pasal 1 ayat (35) Undang-Undang Republik Indonesia Nomor 1 Tahun 2014 Tentang Perubahan Atas Undang-Undang Nomor
} 
Hal penting yang sering terlupakan dalam implementasi kebijakan tersebut adalah bagaimana membuat masyarakat berkeinginan untuk berpartisipasi secara aktif baik itu dalam proses perencanaan, pelaksanaan dan pengawasan pembangunan. Perspektif pengembangan wilayah perbatasan sebagai teras depan bangsa bukan saja terlihat pada infrastruktur yang memadai tetapi juga harus dibarengi dengan pembangunan karakter masyarakat di wilayah tersebut. ${ }^{14}$

\section{PENUTUP}

\section{Kesimpulan}

$\begin{array}{rlr}\text { Wilayah perbatasan yang } \\ \text { merupakan } & \text { halaman depan }\end{array}$

Republik Indonesia harus tetap dijaga dan dilindungi. Penjagaan dan perlindungannyanya melalui orientasi pembangunan kawasan perbatasan yang integratif dan berkesinambungan. Hal ini berarti seluruh komponen bangsa memiliki peran dan tanggungjawab (hak dan kewajiban) yang sama, baik pemerintah, swasta maupun masyarakat dalam memajukan kawasan perbatasan. Integrasi

27 Tahun 2007 Tentang Pengelolaan Wilayah Pesisir dan Pulau-Pulau Kecil. perencanaan, aturan, kelembagaan dan pembiayaan pembangunan harus berlangsung bersama sama yang melibatkan pemerintah dan masyarakat.

Kehadiran Badan Nasional Pengelola Perbatasan (BNPP) diharapkan dapat mewujudkan hasil konkret pembangunan wilayah perbatasan dengan arahan yang jelas. Peran BNPP adalah memberikan petunjuk umum berupa grand design pengelolaan kawasan perbatasan negara. Daerah-daerah yang memiliki kawasan perbatasan akan menjadikan grand design tersebut sebagai acuan rencana aksi pembangunan sesuai karaktersitik wilayah perbatasannya (baik darat maupun perairan).

\section{Saran}

Pemerintah Republik Indonesia hendaknya membuat suatu bentuk produk hukum nasional yang mengatur tentang batas wilayah laut perbatasan antara negara Indonesia dengan negara tetangga. Pemerintah Indonesia hendaknya lebih memperhatikan pembangunan infrastuktur, pendidikan, kesehatan dan perekonomian masyarakat di wilayah perbatasan agar 
masyarakat Indonesia yang tinggal

di perbatasan tidak bergantung pada pada negara luar.

\section{DAFTAR PUSTAKA}

Ane Permatasari. 2014.“Otonomi Khusus Daerah Perbatasan, Alternatif Solusi Penyelesaian Masalah Perbatasan Di Indonesia".Jurnal Media Hukum Volume 21 Nomor 2 Desember 2014.

Aziz Budianta. Februari 2010. "Pengembangan Wilayah Perbatasan Sebagai Upaya Pemerataan Pembangunan Wilayah Di Indonesia”. Jurnal SMARTek Volume 8 Nomor 1.

Eddy MT Sianturidan Nafsiah. 2001. "Strategi Pengembangan Perbatasan Wilayah Kedaulatan NKRI'.Majalah Balitbang Dephan, Jakarta.

Lerry Rupidara. 2010.Policy Paper Pengelolaan Batas Negara dan Kawasan Perbatasan. Badan Pengelolaan Perbatasan Provinsi NTT, Kupang.

Mahendra Putra Kurnia. 2011.Harmonisasi Hukum Pengembangan Kawasan Perbatasan NKRI Berbasis Teknologi Geospasial. UB Press, Malang.

Moh. Mahmud MD. 5 Agustus 2008."Tata Kelola Perbatasan Negara

Kita".Makalah, disampaikan dalam acara Seminar Forum Rektor Indonesia: Keunggulan, Kepeloporan, Kejuangan dan Pengabdian Perguruan Tinggi dalam Membangun Daya Saing dan Martabat Bangsa di Auditorium Kahar Mudzdhakir, UII, Yogyakarta.

Republik Indonesia.Undang-Undang Dasar Negara Republik Indonesia Tahun 1945.

Republik Indonesia. Undang-Undang Nomor 43 Tahun 2008 tentang Wilayah Negara.

Republik Indonesia. 3 Maret 2008.Pandangan dan Pendapat DPD RI terhadap Rancangan Undang-Undang tentang Wilayah Negara. Jakarta, DPD RI.

Republik Indonesia. Undang-Undang Republik Indonesia Nomor 1 Tahun 2014 Tentang Perubahan Atas Undang-Undang Nomor 27 Tahun $2007 \quad$ Tentang Pengelolaan Wilayah Pesisir dan Pulau-Pulau Kecil.

Sri Haryati dan Ahmad Yani. 2007.Geografi Politik. PT. Refika Aditama, Bandung. 